\title{
Association of cytomegalovirus and other pathogens with frailty and diabetes mellitus, but not with cardiovascular disease and mortality in psycho-geriatric patients; a prospective cohort study
}

Michiel B Haeseker ${ }^{1,2^{*}}$, Evelien Pijpers ${ }^{3}$, Nicole HTM Dukers-Muijrers ${ }^{1,2,4}$, Patty Nelemans ${ }^{5}$, Christian JPA Hoebe ${ }^{1,2,4}$, Cathrien A Bruggeman ${ }^{1,2}$, Annelies Verbon ${ }^{6}$ and Valère J Goossens ${ }^{1,2}$

\begin{abstract}
Background: Studies about associations of infections with herpes viruses and other pathogens, such as Chlamydia pneumoniae (CP) and Helicobacter pylori (HP) with cardiovascular disease (CVD), diabetes mellitus (DM), frailty and/or mortality are conflicting. Since high levels of antibodies against these pathogens occur in the elderly, the role of these pathogens in morbidity and mortality of vulnerable elderly was explored.

Results: Blood samples of 295 community dwelling psycho-geriatric patients were tested for lgG antibodies to herpes simplex virus type 1 and 2, varicella zoster virus, Epstein Barr virus (EBV), cytomegalovirus (CMV), human herpes virus type 6 (HHV6), CP and HP. Frailty was defined with an easy-to-use previously described frailty risk score. Relative risks (RR) with 95\% confidence intervals were calculated to evaluate associations between CVD, DM, frailty and pathogens. Pathogens as a predictor for subsequent mortality were tested using Kaplan Meier analyses and Cox proportional hazard models. The mean age was 78 (SD: 6.7) years, 20\% died, $44 \%$ were defined as frail, 20\% had DM and 49\% had CVD. Presence of CMV antibody titers was associated with frailty, as shown by using both qualitative and quantitative tests, RR ratio 1.4 (95\% Cl: 1.003-2.16) and RR ratio 1.5 (95\% Cl: 1.06-2.30), respectively. High IgG antibody titers of HHV6 and EBV were associated with DM, RR ratio 3.3 (95\% Cl: 1.57-6.49). None of the single or combined pathogens were significantly associated with mortality and/or CVD.
\end{abstract}

Conclusions: Prior CMV infection is associated with frailty, which could be in line with the concept that CMV might have an important role in immunosenescence, while high IgG titers of HHV6 and EBV are associated with DM. No association between a high pathogen burden and morbidity and/or mortality could be demonstrated.

Keywords: Herpes viruses, Cytomegalovirus, Frailty, Diabetes mellitus, Morbidity, Mortality

\footnotetext{
* Correspondence: m.haeseker@mumc.nl

'Department of Medical Microbiology, Maastricht University Medical Centre,

P. Debyelaan 25, PO Box 5800, 6202 AZ Maastricht, the Netherlands

${ }^{2}$ Care and Public Health Research Institute (CAPHRI), PO Box 616, 6200 MD

Maastricht, the Netherlands

Full list of author information is available at the end of the article
} 


\section{Background}

Age related frailty and chronic diseases, such as diabetes mellitus (DM) and cardiovascular disease (CVD) will increase in developed countries, as the number of elderly people in the developed countries is increasing. A quarter of the population in most European countries will be above 65 years in the near future [1]. The pathophysiological mechanisms of ageing and frailty and the exact causal mechanisms of DM and CVD are not completely understood. Chronic inflammation and prior infections with herpes viruses, Chlamydia pneumonia (CP) and Helicobacter pylori (HP) are suggested to play a role in ageing, frailty, DM and CVD [2-7].

Ageing is associated with deleterious changes in the immune system called immune senescence which have been observed in all mammals studies thus far [8]. Persistent cytomegalovirus (CMV) infections, but no other herpes virus infections have been found to increase immunosenescence [8]. For instance, progressive accumulation of CD 8+ T-cells is correlated with seropositivity to CMV infection [9-12]. It has been hypothesized that accumulation of CD8+ T-cells against one virus reduces the immunity to other pathogens $[13,14]$ which is illustrated by the association of CMV seropositivity with non-responsiveness to anti-influenza vaccination [15]. Furthermore, chronic stimulation of the immune system by CMV may lead to an increasing prevalence of senescent dysfunctional $\mathrm{T}$ cells thereby contributing to mortality and frailty [5,14]. Also, Epstein-Barr virus (EBV) has been associated with a remarkable accumulation of EBV specific CD8 T-cells of up to 30\% [13,14].

Some seroepidemiological studies have shown associations between infections with herpes viruses and other common pathogens such as $\mathrm{CP}$ and $\mathrm{HP}$ on one side and on the other side DM, atherosclerosis, dementia, cognitive impairment, and frailty [2-7]. The exact causal mechanisms are not yet known, although chronic inflammation, which is a risk factor for DM type 2 [16], has been hypothesized to be caused by the presence of persistent infection. Indeed, CMV, varicella zoster virus (VZV) and herpes simplex virus (HSV) have been associated with the occurrence of DM in some studies [6,17-19], but other studies could not confirm this association with DM [20]. Similarly, herpes viruses, HP and CP infections have been associated with atherosclerosis and CVD [2,7], whereas others could not confirm these findings [21,22].

Overall, the concept of accelerating immunosenescence by persistent infections and subsequent increased mortality and morbidity has been suggested in some studies. The aim of this study is to determine associations between frailty, CVD, DM and mortality with single pathogens and combined pathogen burden among prospectively followed community dwelling psycho-geriatric patients.

\section{Results}

\section{Pathogens and morbidity}

A total of 295 blood samples were collected from community dwelling psycho-geriatric patients between October 2002 and December 2005. The mean age of these patients was 78.0 years \pm 6.7 years and $64 \%(n=188)$ were female. The median follow-up period of the surviving patients was 25 months (range: 12-36 months). Forty four percent ( $\mathrm{n}=$ $131 / 295)$ of the patients were considered frail, $20 \%(n=59 /$ 295) had DM (all patients had DM type 2) and $48 \%(\mathrm{n}=$ 143/295) with CVD. Twenty percent of the 295 patients $(n=60)$ died during the study period of 36 months. Frequencies for single pathogens and pathogen burden are shown in Table 1. VZV and EBV seronegative patients were very small, only 3 and 4 patients respectively. Additionally, $46 \%(n=136)$ were positive for all herpes viruses tested.

None of the single pathogens were significantly associated with CVD, but an association between seropositivity for CMV and frailty (Tables 1 and 2) and association between high human herpes virus type 6 (HHV6) and high EBV antibody titers and DM was observed (Table 3). Neither the total herpes burden (data not shown), nor the pathogen burden (Table 1) was significantly associated with CVD, DM and/or frailty. Additionally, CMV avidity was not associated with CVD or DM.

\section{Pathogens and mortality}

Seropositivity of single pathogens was associated with increased relative risks (RR) of mortality, but these results did not reach statistical significance (Table 4). After adjustment for frailty most relative risks decreased. Almost all patients (Table 1) were seropositive for VZV and EBV. Therefore, VZV and EBV were left out Table 4.

\section{CMV seropositivity and frailty}

Of 295 patients, 67 were CMV IgG negative both by AxSYM and DSX ${ }^{\mathrm{m}}$. Two hundred and twenty six patients were CMV IgG positive both by AxSYM and DSX ${ }^{\mathrm{m}}$. Discordance was limited to 2 weakly positive results for DSX ${ }^{\text {su }}$ $(44.20 \mathrm{U} / \mathrm{ml}$ and $49.10 \mathrm{U} / \mathrm{ml})$ and negative results for AxSYM $(0.80 \mathrm{AU} / \mathrm{ml}$ and $2.10 \mathrm{AU} / \mathrm{ml})$, confirmed by negative results with Vidas, low CMV IgG avidity and/or CMV IgM negative results by DSX ${ }^{\mathrm{m}}$ and considered negative.

Overall, 76.6\% $(\mathrm{n}=226)$ of the geriatric patients was CMV IgG seropositive. Only 1 patient was CMV IgM seropositive with low value. CMV was associated with frailty, RR 1.4 (95\% CI: 1.003-2.16) and the quantitative tests showed that the highest CMV IgG titers were more often found in the frailty group RR 1.5 (95\% CI: 1.06-2.30), see Table 2. Mean CMV avidity was high 76.2\% (SD = 7.9).

\section{Herpesviruses and DM}

HHV6 IgG was associated with DM RR 1.7 (95\% CI: 0.96-3.13). The quantitative tests demonstrated that high 
Table 1 Frequencies for pathogens and the associations between the different pathogens, cardiovascular disease (CVD), diabetes mellitus (DM) and frailty

\begin{tabular}{|c|c|c|c|c|c|c|}
\hline Serology test & $\begin{array}{l}\text { Range of test } \\
(\mathrm{U} / \mathrm{ml})\end{array}$ & $\begin{array}{l}\text { Median (IQR) } \\
\text { Titer (U/ml) }\end{array}$ & $\begin{array}{l}\text { Total } \\
\text { number(\%) }\end{array}$ & $\begin{array}{l}\mathrm{DM}+ \\
(n=59)\end{array}$ & $\begin{array}{l}\text { CVD+ } \\
(n=143)\end{array}$ & $\begin{array}{l}\text { Frail+ } \\
(n=131)\end{array}$ \\
\hline HSV $^{\mathrm{a}}$ IgG positive & $30-2000$ & 437 (389-484) & 275 (93\%) & $57(97 \%)$ & $133(93 \%)$ & $122(93 \%)$ \\
\hline HSV $^{\mathrm{a}}$ IgG negative & & - & $20(7 \%)$ & $2(3 \%)$ & $10(7 \%)$ & $9(7 \%)$ \\
\hline VZV $^{\mathrm{a}}$ IgG positive & $100-2000$ & $994(612-1403)$ & $292(99 \%)$ & $59(100 \%)$ & 141 (99\%) & 128 (98\%) \\
\hline VZV $^{\mathrm{a}}$ IgG negative & & - & $3(1 \%)$ & $0(0 \%)$ & $2(1 \%)$ & $3(2 \%)$ \\
\hline EBV $^{\mathrm{a}}$ IgG positive & $11-200$ & $200(130-200)$ & $291(99) \%$ & $58(98 \%)$ & 141 (99\%) & 128 (98\%) \\
\hline EBV $^{\mathrm{a}}$ IgG negative & & - & $4(1 \%)$ & $1(2 \%)$ & $2(1 \%)$ & $3(2 \%)$ \\
\hline $\mathrm{CMV}^{\mathrm{a}}$ IgG positive & & & $226(77 \%)$ & $46(78 \%)$ & $115(80 \%)$ & $108(82 \%)^{b}$ \\
\hline - AxSYM & $15-250$ & $250(192-250)$ & & & & \\
\hline$\cdot \mathrm{DSX}^{\mathrm{TM}}$ & $40-2000$ & $373(290-463)$ & & & & \\
\hline $\mathrm{CMV}^{\mathrm{a}}$ IgG negative & & - & 69 (23\%) & $13(22 \%)$ & $28(20 \%)$ & $23(18 \%)^{b}$ \\
\hline HHV6 $^{\mathrm{a}}$ IgG positive & $>1.1$ & $1.67(1.37-2.34)$ & $193(65 \%)$ & $45(76 \%)^{c}$ & 97 (68\%) & 90 (69\%) \\
\hline HHV6 $^{\mathrm{a}}$ IgG negative & & - & $102(35 \%)$ & $14(24 \%)^{c}$ & 46 (32\%) & 41 (31\%) \\
\hline $\mathrm{CP}^{\mathrm{a}}$ IgG positive & $45-270$ & $81(59-116)$ & $150(51 \%)$ & $28(47 \%)$ & 74 (52\%) & $68(52 \%)$ \\
\hline $\mathrm{CP}^{\mathrm{a}}$ IgG negative & & - & $144(49 \%)$ & $31(53 \%)$ & $69(48 \%)$ & $63(48 \%)$ \\
\hline HP $^{\mathrm{a}}$ IgG positive & $20-650$ & $97(36-211)$ & $173(59 \%)$ & $32(54 \%)$ & $82(47 \%)$ & 77 (59\%) \\
\hline $\mathrm{HP}^{\mathrm{a}}$ IgG negative & & - & $121(41 \%)$ & $27(46 \%)$ & $61(43 \%)$ & 54 (41\%) \\
\hline Pathogen burden ${ }^{d}$ & & - & & & & \\
\hline - Pathogen burden $\leq 4$ & & & $53(18 \%)$ & $9(15 \%)$ & $25(18 \%)$ & $18(14 \%)$ \\
\hline - Pathogen burden $=5$ & & - & $95(32 \%)$ & $18(31 \%)$ & $46(32 \%)$ & $44(33 \%)$ \\
\hline - Pathogen burden = 6 & & - & $103(35 \%)$ & $23(39 \%)$ & $46(32 \%)$ & 48 (37\%) \\
\hline - Pathogen burden = 7 & & - & $44(15 \%)$ & $9(15 \%)$ & $26(18 \%)$ & $21(16 \%)$ \\
\hline
\end{tabular}

HHV6 IgG antibody titers RR 3.8 (95\% CI: 1.42-5.36) and high EBV antibody titers RR 1.7 (95\% CI: 1.04-2.91) were associated with DM, Table 3. An additional effect is demonstrated when high HHV6 antibody titers and high EBV antibody titers are combined RR 3.3 (95\% CI: 1.576.49), Table 3. Antibody titers of HSV, VZV, CMV, CP and HP were not associated with DM.

\section{Discussion}

Prior infections with herpes viruses, HP and CP are reported to be associated with mortality and morbidity (i.e. CVD, DM and frailty), although the results of different studies are often conflicting [2-7,20-22]. Here, 8 pathogens were tested both qualitative and quantitative in geriatric patients. No robust association between the pathogen

Table 2 Association between frailty and cytomegalovirus (CMV) IgG titer (AxSYM and DSX ${ }^{\mathrm{Tm}}$ )

\begin{tabular}{llllll}
\hline Test & CMV result & $\mathbf{N}$ & $\begin{array}{l}\text { Frailty + } \\
(\mathbf{n = 1 3 1 )}\end{array}$ & $\begin{array}{l}\text { Frailty - } \\
(\mathbf{n}=\mathbf{1 6 4 )}\end{array}$ \\
\hline AxSYM & CMV titer: $<15 \mathrm{AU} / \mathrm{ml}$ & $23(17.5 \%)$ & $46(28.4 \%)$ \\
& CMV titer: $15-192 \mathrm{AU} / \mathrm{ml}$ & 59 & $22(17.0 \%)$ & $33(20.4 \%)$ & $1.2(0.71-2.00)$ \\
& CMV titer: $\geq 192 \mathrm{AU} / \mathrm{ml}$ & 169 & $86(65.5 \%)$ & $83(51.2 \%)$ & $1.5(1.06-2.30)$ \\
DSX $^{\mathbf{m}}$ & CMV titer: $<40 \mathrm{U} / \mathrm{ml}$ & 67 & $22(16.8 \%)$ & $45(27.44 \%)$ & $34(20.73 \%)$ \\
& CMV titer: $40-290 \mathrm{U} / \mathrm{ml}$ & 56 & $22(16.8 \%)$ & $85(51.83 \%)$ & $1.2(0.72-2.03)$ \\
& CMV titer: $\geq 290 \mathrm{U} / \mathrm{ml}$ & 172 & $87(66.4 \%)$ & & $1.06-2.35)$ \\
\hline
\end{tabular}


Table 3 Association between diabetes mellitus (DM) and antibody titers to human herpes virus (HHV6) and epstein-barr virus (EBV)

\begin{tabular}{|c|c|c|c|c|}
\hline Test result & $\mathrm{N}$ & $\begin{array}{l}\mathrm{DM}+ \\
(\mathrm{n}=59)\end{array}$ & $\begin{array}{l}D M- \\
(n=236)\end{array}$ & RR ratio $(95 \% \mathrm{Cl})$ \\
\hline \multicolumn{5}{|l|}{ HHV6 } \\
\hline - HHV6 titer: $<1.1$ & 103 & $14(23.7 \%)$ & $89(37.7 \%)$ & \\
\hline - HHV6 titer: 1.1-2.3 & 144 & $27(45.8 \%)$ & $117(49.6 \%)$ & $1.38(0.74-2.66)$ \\
\hline - HHV6 titer: $>2.3$ & 48 & $18(30.5 \%)$ & $30(12.7 \%)$ & $2.76(1.42-5.36)$ \\
\hline \multicolumn{5}{|l|}{ EBV } \\
\hline - EBV titer: 0-200 U/ml & 144 & $21(35.6 \%)$ & $123(52.1 \%)$ & \\
\hline - EBV titer: $\geq 200 \mathrm{U} / \mathrm{ml}$ & 151 & $38(64.4 \%)$ & $113(47.9 \%)$ & $1.73(1.04-2.91)$ \\
\hline \multicolumn{5}{|l|}{ HHV6 and EBV } \\
\hline - HHV6 titer $<1.1$ and EBV titer 0-200 & 127 & $15(25.4 \%)$ & $112(47.5 \%)$ & \\
\hline - HHV6 titer 1.1-2.3 and EBV titer $>=200$ or HHV6 titer $>2.3$ and EBV titer 0-200 & 137 & $32(54.2 \%)$ & $105(44.5 \%)$ & $2.28(1.1-4.7)$ \\
\hline - HHV6 titer $>2.3$ and EBV titer $>=200$ & 31 & $12(20.4 \%)$ & $19(8.0 \%)$ & $3.28(1.57-6.49)$ \\
\hline
\end{tabular}

burden and mortality was found, although all single pathogens showed increased relative risks with mortality. No associations were found between single pathogens or combined pathogens and CVD. DM was associated with two herpes viruses, i.e. HHV6 and EBV, and an association was demonstrated between frailty and CMV.

The association between CMV and frailty was also found by Schmaltz et al. [5]. Whereas Schmaltz et al. reported an association between CMV and frailty in 724 community dwelling women [5], we demonstrated this association in both men and women. Furthermore, we have performed at least 2 quantitative tests for CMV IgG, a quantitative test for CMV IgM and a test for CMV avidity in order to obtain a more complete CMV serology status. The highest CMV IgG titers were found in frail older people and suggest a dose-response relation, as elevated IgG titers to CMV among seropositive non-immunocompromised individuals suggest frequent viral reactivations [23]. No significant association between CMV (and other pathogens) and mortality was found. Power may be too low to show effects of CMV on mortality. The causal mechanism of the association between CMV and frailty is

Table 4 Unadjusted and adjusted mortality hazard ratios for frailty with $\mathbf{9 5 \%}$ confidence intervals

\begin{tabular}{lll}
\hline & Unadjusted RR (95\% Cl) & Adjusted for frailty RR (95\% Cl) \\
\hline HSV $^{\mathrm{a}}$ & $1.23(0.38-3.93)$ & $1.24(0.39-3.96)$ \\
$\mathbf{C M V}^{\mathrm{b}}$ & $1.60(0.81-3.15)$ & $1.20(0.61-2.39)$ \\
HHV6 $^{c}$ & $1.00(0.59-1.71)$ & $0.88(0.5-1.49)$ \\
CP $^{d}$ & $1.07(0.64-1.77)$ & $1.06(0.64-1.76)$ \\
HP $^{\mathrm{e}}$ & $1.26(0.75-2.13)$ & $1.24(0.73-2.09)$ \\
\hline
\end{tabular}

${ }^{\mathrm{a}} H S V$ : herpes simplex virus.

${ }^{\mathrm{b}} \mathrm{CMV}$ : cytomegalovirus.

${ }^{\mathrm{C}} H$ HV6: human herpes virus type 6.

${ }^{\mathrm{d}} C P$ : Chlamydia pneumonia.

${ }^{\mathrm{e}} H P$ : Helicobacter pylori. not yet clear. The association between CMV and frailty could be in line with the concept that CMV might have an important role in immunosenescence [8]. Understanding the role of $\mathrm{CMV}$ in the immunosenescence hypothesis more clearly may elucidate the association between CMV and frailty. Therefore, it would be interesting to investigate alterations in the immune system, such as CD4/CD8 ratio's, in these frail patients. Taken together, an association between CMV and frailty was found.

A recent study showed that in the above 85 year olds CMV seropositivity was higher in patients with DM [19], unfortunately no other pathogens were determined in that study. In our study the CMV seropositivity was only slightly higher in patients with DM. However, DM type 2 was related to the presence of high EBV IgG titers and high HHV6 response. Two case reports have described the development of a type 1 DM with HHV6 reactivation $[24,25]$ and two other case reports during an acute EBV infection [26,27]. Reactivations of both viruses could play a role in DM and in the chronic systemic inflammation in DM [3,6,24,25], since high EBV IgG titers and a high HHV6 response suggests reactivation $[28,29]$. It is unlikely that the presence of DM has resulted in increased antiHHV6 or EBV antibody titers since anti-viral antibody levels are decreased rather than increased in patients with DM [18,30]. However, little is known about possible causative mechanisms and more evidence is needed to support this association.

One of the strengths of this study is the large number of pathogens that have been studied in this well defined prospectively followed elderly people group. High antibody titers, together with a high CMV avidity in all CMV positive patients indicate non-primary past or recurrent infection [31]. Antibody titers have been useful to study the doseresponse relation. In future research measuring a combination of humoral and cellular immunity markers and 
persisting viral replication and viral gene expression might be valuable for revealing the role of herpes viruses in mortality and morbidity, especially frailty and DM. Understanding the role of CMV in the immunosenescence hypothesis more clearly may elucidate the association between CMV and frailty.

\section{Conclusion}

Of the 8 pathogens studied in this community dwelling psycho-geriatric patients associations have been shown between prior CMV infection and frailty, which could be in line with the concept that CMV might have an important role in immunosenescence and an association between DM and prior infection with HHV6 and EBV was demonstrated. We could not demonstrate an association between a high pathogen burden and morbidity and/or mortality.

\section{Methods}

\section{Study population}

Data from a study with community dwelling psychogeriatric patients attending the Diagnostic Observation Centre for Psycho Geriatric patients of the Maastricht University Medical Centre between October 2002 and December 2005 were used. For all patients the frailty score, the presence of DM and that of CVD was determined, and blood samples were collected when patients were included. Frailty was defined with an easy-to-use previously described frailty risk score [32]. The frailty score was calculated with the following rule: Age (per 10 years) $\times 4+$ male sex x $10+$ no partner $\times 5+$ BMI < $18.5 \mathrm{~kg} / \mathrm{m} 2+$ cardiovascular disease $\mathrm{x} 4+$ ADL process deficit $x 7$. The mean of the frailty score was 52 (median: 51 , range: $28-76$ ). The cut-off for frailty was set on $\geq 53$ points" [32].

DM was defined as a history of DM or an elevated fasting glucose and increased HBA1c. CVD in this study was defined from hypertension to severe CVD. Patients were prospectively followed for 36 months.

This study was approved by the medical ethical committee of the Maastricht University Medical Centre. Written informed consent was obtained from the patient for the publication of this report and any accompanying images.

\section{Laboratory techniques}

The blood samples were stored as plasma at $-80^{\circ} \mathrm{C}$. All blood samples were tested for immunoglobulin $\mathrm{G}$ (IgG) to detect antibodies to HSV type 1 and 2, VZV, EBV (Virion) Serion, Würzberg, Germany), CMV (AxSYM, Abbott laboratories, Abbott Park, USA and Virion\Serion, Würzberg and in case of discordance also Vidas, BioMérieux Marcy l'Etoile, France), HHV6 (Panbio diagnostics, Grenoble, France), HP (Orion Diagnostica, Espoo, Finland) and to CP (Anilabsystems Ltd., Vantaa, Finland). Additionally, immunoglobulin M (IgM) and CMV IgG avidity (Virion\
Serion, Würzberg, Germany) were tested. All antibodies were tested with quantitative enzyme immunoassay (EIA) on the DSX $^{\text {тм }}$ Fourplate Automated Elisa processing system, Chantilly, USA. HSV IgG was positive if antibodies were between 30 and $2000 \mathrm{U} / \mathrm{ml}$, VZV IgG 100$2000 \mathrm{U} / \mathrm{ml}$, EBV IgG 11-200 U/ml, CMV IgG AxSYM 15-250 AU/ml, CMV IgG Dynex 40-2000 U/ml, HHV6 IgG >1.1, CP IgG 45-270 U/ml and HP IgG 20$650 \mathrm{U} / \mathrm{ml}$. Further classification of the CMV, EBV and HHV6 titers were made in weakly positive and strongly positive based on the interquartile range. For CMV the lower quartile (AxSYM: $<192 \mathrm{AU} / \mathrm{ml}$ and $\mathrm{DSX}^{\mathrm{Tm}}$ : $<290 \mathrm{U} / \mathrm{ml}$ ) was considered weakly positive and the quartiles above $192 \mathrm{AU} / \mathrm{ml}$ (AxSYM) and above $290 \mathrm{U} / \mathrm{ml}\left(\mathrm{DSX}^{\mathrm{Tm}}\right)$ as strongly positive. For EBV the quartiles below $200 \mathrm{U} / \mathrm{ml}$ were considered weakly positive and the quartiles $\geq$ $200 \mathrm{U} / \mathrm{ml}$ were considered strongly positive. For HHV6 the highest quartile $(\geq 2.3 \mathrm{U} / \mathrm{ml})$ was considered strongly positive and the quartiles lower than $2.3 \mathrm{U} / \mathrm{ml}$ as weakly positive. All tests were performed according to the manufactures' instructions.

\section{Statistical analysis}

Prevalence rates were calculated for single infection, herpes burden (aggregated seropositivity to IgG antibodies for HSV1-2, VZV, EBV, CMV and HHV6) and pathogen burden (aggregated seropositivity to IgG antibodies for the herpes burden, CP and HP). The associations between disease (CVD, DM) or frailty and seropositivity for pathogens at baseline were expressed as relative risks with 95\% confidence intervals. Chi-square tests and analysis of variance (ANOVA) were performed to test for statistical significance. Kaplan Meier survival analysis and Cox proportional hazard models were used to evaluate whether seropositivity for pathogens is associated with higher risk of subsequent mortality. Follow-up time was calculated from the date of inclusion to the date of death or the date of last follow-up (censoring date). Hazard ratios with 95\% confidence intervals (unadjusted and adjusted for frailty) were calculated. A $P$-value of $<0.05$ was considered statistically significant. Analyses were carried out with SPSS 16.0 (SPSS Inc., Chicago, USA).

\section{Competing interests}

The authors declare that they have no competing interests.

\section{Authors' contributions}

$\mathrm{MH}, \mathrm{EP}, \mathrm{CH}, \mathrm{ND}$ and $\mathrm{PN}$ carried out the data analysis. CB, VG an AV participated in design of the study. MH, ND, VG, PN and AV drafted the manuscript. All authors have read and approved the final version manuscript.

\section{Acknowledgements}

The authors would like to acknowledge patients and staff of the DOC-PG in Maastricht and all the analysts of the clinical virology laboratory of the Maastricht University Medical Centre. This work was supported by Care and Public Health Research Institute (CAPHRI). 


\section{Author details}

1 Department of Medical Microbiology, Maastricht University Medical Centre P. Debyelaan 25, PO Box 5800, 6202 AZ Maastricht, the Netherlands. ${ }^{2}$ Care and Public Health Research Institute (CAPHRI), PO Box 616, 6200 MD Maastricht, the Netherlands. ${ }^{3}$ Department of Internal Medicine, Maastricht University Medical Centre, Maastricht, the Netherlands. ${ }^{4}$ Department of Infectious Diseases, Public Health Services South Limburg, South Limburg, Geleen, the Netherlands. ${ }^{5}$ Department of Epidemiology, Maastricht University Medical Centre, Maastricht, the Netherlands. ${ }^{6}$ Department of Internal Medicine, Erasmus Medical Centre, Rotterdam, the Netherlands.

Received: 16 January 2013 Accepted: 21 July 2013

Published: 23 July 2013

\section{References}

1. Eurostat: Populations projections 2010-2060; 2010. http://epp.eurostat.ec. europa.eu/cache/ITY_PUBLIC/3-08062011-BP/EN/3-08062011-BP-EN.PDF.

2. Espinola-Klein C, Rupprecht HJ, Blankenberg S, Bickel C, Kopp H, Rippin G, Victor A, Hafner G, Schlumberger W, Meyer J: Impact of infectious burden on extent and long-term prognosis of atherosclerosis. Circulation 2002, 105:15-21.

3. Fernandez-Real JM, Lopez-Bermejo A, Vendrell J, Ferri MJ, Recasens M, Ricart W: Burden of infection and insulin resistance in healthy middle-aged men. Diabetes Care 2006, 29:1058-1064.

4. Letenneur L, Peres K, Fleury H, Garrigue I, Barberger-Gateau P, Helmer C, Orgogozo JM, Gauthier S, Dartigues JF: Seropositivity to herpes simplex virus antibodies and risk of Alzheimer's disease: a population-based cohort study. PLoS One 2008, 3:e3637.

5. Schmaltz HN, Fried LP, Xue QL, Walston J, Leng SX, Semba RD: Chronic cytomegalovirus infection and inflammation are associated with prevalent frailty in community-dwelling older women. J Am Geriatr Soc 2005, 53:747-754.

6. Sun $Y$, Pei $W, W u$ Y, Yang $Y$ : An association of herpes simplex virus type 1 infection with type 2 diabetes. Diabetes Care 2005, 28:435-436.

7. Zhu J, Nieto FJ, Horne BD, Anderson JL, Muhlestein JB, Epstein SE: Prospective study of pathogen burden and risk of myocardial infarction or death. Circulation 2001, 103:45-51.

8. Pawelec G, Derhovanessian E, Larbi A, Strindhall J, Wikby A: Cytomegalovirus and human immunosenescence. Rev Med Virol 2009, 19:47-56.

9. Khan N, Shariff N, Cobbold M, Bruton R, Ainsworth JA, Sinclair AJ, Nayak L, Moss PA: Cytomegalovirus seropositivity drives the CD8 T cell repertoire toward greater clonality in healthy elderly individuals. J Immunol 2002, 169:1984-1992.

10. Looney RJ, Falsey A, Campbell D, Torres A, Kolassa J, Brower C, McCann R, Menegus M, McCormick K, Frampton M, Hall W, Abraham GN: Role of cytomegalovirus in the T cell changes seen in elderly individuals. Clin Immunol 1999, 90:213-219.

11. Schwab R, Szabo P, Manavalan JS, Weksler ME, Posnett DN, Pannetier C, Kourilsky P, Even J: Expanded CD4+ and CD8+ T cell clones in elderly humans. J Immunol 1997, 158:4493-4499.

12. Wikby A, Johansson B, Olsson J, Lofgren S, Nilsson BO, Ferguson F: Expansions of peripheral blood CD8 T-lymphocyte subpopulations and an association with cytomegalovirus seropositivity in the elderly: the Swedish NONA immune study. Exp Gerontol 2002, 37:445-453.

13. Khan N, Hislop A, Gudgeon N, Cobbold M, Khanna R, Nayak L, Rickinson AB, Moss PA: Herpesvirus-specific CD8 T cell immunity in old age: cytomegalovirus impairs the response to a coresident EBV infection. $J$ Immunol 2004, 173:7481-7489.

14. Pawelec G, Akbar A, Caruso C, Effros R, Grubeck-Loebenstein B, Wikby A: Is immunosenescence infectious? Trends Immunol 2004, 25:406-410.

15. Trzonkowski P, Mysliwska J, Szmit E, Wieckiewicz J, Lukaszuk K, Brydak LB, Machala M, Mysliwski A: Association between cytomegalovirus infection, enhanced proinflammatory response and low level of antihemagglutinins during the anti-influenza vaccination-an impact of immunosenescence. Vaccine 2003, 21:3826-3836.

16. Pradhan AD, Manson JE, Rifai N, Buring JE, Ridker PM: C-reactive protein, interleukin 6, and risk of developing type 2 diabetes mellitus. JAMA 2001, 286:327-334.

17. Roberts BW, Cech I: Association of type 2 diabetes mellitus and seroprevalence for cytomegalovirus. South Med J 2005, 98:686-692.
18. Okamoto S, Hata A, Sadaoka K, Yamanishi K, Mori Y: Comparison of varicella-zoster virus-specific immunity of patients with diabetes mellitus and healthy individuals. J Infect Dis 2009, 200:1606-1610.

19. Chen S, Jm De Craen A, Raz Y, Derhovanessian E, Vossen Ctm A, Westendorp Gj R, Pawelec G, Maier AB: Cytomegalovirus seropositivity is associated with glucose regulation in the oldest old. results from the leiden 85-plus study. Immun Ageing 2012, 9:18.

20. Lutsey PL, Pankow JS, Bertoni AG, Szklo M, Folsom AR: Serological evidence of infections and type 2 diabetes: the MultiEthnic study of Atherosclerosis. Diabet Med 2009, 26:149-152.

21. Danesh J, Wong Y, Ward M, Muir J: Chronic infection with Pelicobacter pylori, Chlamydia pneumoniae, or cytomegalovirus: population based study of coronary heart disease. Heart 1999, 81:245-247.

22. Hagiwara N, Toyoda K, Inoue T, Shimada H, Ibayashi S, lida M, Okada Y: Lack of association between infectious burden and carotid atherosclerosis in japanese patients. J Stroke Cerebrovasc Dis 2007, 16:145-152.

23. McVoy MA, Adler SP: Immunologic evidence for frequent age-related cytomegalovirus reactivation in seropositive immunocompetent individuals. J Infect Dis 1989, 160:1-10.

24. Chiou CC, Chung WH, Hung SI, Yang LC, Hong HS: Fulminant type 1 diabetes mellitus caused by drug hypersensitivity syndrome with human herpesvirus 6 infection. J Am Acad Dermatol 2006, 54:S14-S17.

25. Sekine N, Motokura T, Oki T, Umeda Y, Sasaki N, Hayashi M, Sato H, Fujita T, Kaneko T, Asano Y, Kikuchi K: Rapid loss of insulin secretion in a patient with fulminant type 1 diabetes mellitus and carbamazepine hypersensitivity syndrome. JAMA 2001, 285:1153-1154.

26. Burgess JA, Kirkpatrick KL, Menser MA: Fulminant onset of diabetes mellitus during an attack of infectious mononucleosis. Med J Aust 1974, 2:706-707.

27. Parkkonen P, Hyoty H, Ilonen J, Reijonen H, Yla-Herttuala S, Leinikki P: Antibody reactivity to an epstein-barr virus BERF4-encoded epitope occurring also in Asp-57 region of HLA-DQ8 beta chain. childhood diabetes in finland study group. Clin Exp Immunol 1994, 95:287-293.

28. Fox JD, Ward P, Briggs M, Irving W, Stammers TG, Tedder RS: Production of IgM antibody to HHV6 in reactivation and primary infection. Epidemiol Infect 1990, 104:289-296.

29. Rahman MA, Kingsley LA, Atchison RW, Belle S, Breinig MC, Ho M, Rinaldo CR Jr: Reactivation of epstein-barr virus during early infection with human immunodeficiency virus. J Clin Microbiol 1991, 29:1215-1220.

30. Krause I, Anaya JM, Fraser A, Barzilai O, Ram M, Abad V, Arango A, Garcia J, Shoenfeld $Y$ : Anti-infectious antibodies and autoimmune-associated autoantibodies in patients with type I diabetes mellitus and their close family members. Ann N Y Acad Sci 2009, 1173:633-639.

31. Grangeot-Keros L, Mayaux MJ, Lebon P, Freymuth F, Eugene G, Stricker R, Dussaix E: Value of cytomegalovirus (CMV) IgG avidity index for the diagnosis of primary CMV infection in pregnant women. J Infect Dis 1997, 175:944-946.

32. Pijpers E, Ferreira I, van de Laar RJ, Stehouwer CD, Nieuwenhuijzen Kruseman AC: Predicting mortality of psychogeriatric patients: a simple prognostic frailty risk score. Postgrad Med J 2009, 85:464-469.

\section{doi:10.1186/1742-4933-10-30}

Cite this article as: Haeseker et al: Association of cytomegalovirus and other pathogens with frailty and diabetes mellitus, but not with cardiovascular disease and mortality in psycho-geriatric patients; a prospective cohort study. Immunity \& Ageing 2013 10:30.

\section{Submit your next manuscript to BioMed Central and take full advantage of:}

- Convenient online submission

- Thorough peer review

- No space constraints or color figure charges

- Immediate publication on acceptance

- Inclusion in PubMed, CAS, Scopus and Google Scholar

- Research which is freely available for redistribution 